\section{Comparative bacteriology of acute and chronic dacryocystitis}

MJ Bharathi', R Ramakrishnan², V Maneksha ${ }^{3}$, C Shivakumar ${ }^{3}$, V Nithya $^{1}$ and S Mittal ${ }^{2}$

\begin{abstract}
Aims To compare the bacterial aetiology and their in vitro antibacterial susceptibilities of acute and chronic dacryocystitis.

Methods A retrospective analysis of patients with clinically diagnosed acute and chronic dacryocystitis who underwent microbiological evaluation presenting between January 2000 and December 2005 was carried out. Mucopurulent discharge through punctum, pus from burst abscess, incision drainage, and lacrimal sac content were taken and subjected to microbiological evaluation.
\end{abstract}

Results A total of 1891 patients of dacryocystitis were evaluated and subjected to microbiological evaluation, of which 566 $\mathbf{2} 29.9 \%)$ had acute dacryocystitis and 1325 $\mathbf{7 0 . 1 \% )}$ had chronic dacryocystitis. Of 1891 eyes, $1518(80.3 \%)$ had pure bacterial growth and the remaining $373(19.7 \%)$ had no growth. The percentage of culture-positivity was found to be higher in chronic dacryocystitis (90\%) than in acute dacryocystitis $\mathbf{( 5 7 . 4 \% )}$ $(P<0.0001)$. A total of 1612 bacterial isolates were recovered from 325 acute and 1193 chronic dacryocystitis; in 1424 (93.8\%) eyes, single bacterial species was isolated, and in the remaining $94(6.2 \%)$ eyes, two bacterial species were isolated. The predominant bacterial pathogen isolated from acute dacryocystitis was Staphylococcus aureus (22.3\%) followed by Pseudomonas aeruginosa $\mathbf{2} 1.1 \%)$ and from chronic dacryocystitis was coagulase-negative staphylococci (CoNS) (44.2\%), S. aureus (10.8\%), and Streptococcus pneumoniae (10\%). The highest percentage of bacterial isolates were susceptible to gatifloxacin $(96.5 \%)$, ofloxacin $(94.8 \%)$, and amikacin $(\mathbf{9 1 . 1 \%})$. The percentage of resistance of bacterial isolates recovered from chronic dacryocystitis to gentamicin $(45.7 \%)$, tobramycin $(50.8 \%)$, norfloxacin $(50.7 \%)$, and ciprofloxacin $(30.4 \%)$ were found to be higher than that of bacterial isolates from acute infection to gentamicin $(24.6 \%)$, tobramycin $(35 \%)$, norfloxacin $(36.5 \%)$, and ciprofloxacin (19.9\%).

Conclusion The proportions of $S$. aureus and Pseudomonas spp are higher in causing acute dacryocystitis, while the proportion of CoNS is higher in chronic dacryocystitis. The percentages of antibacterial resistant isolates were higher among bacterial species from chronic dacryocystitis.

Eye (2008) 22, 953-960; doi:10.1038/sj.eye.6702918; published online 29 June 2007

Keywords: acute dacryocystitis; chronic dacryocystitis; culture; bacterial pathogens; antibacterial susceptibilities; antibacterial resistances

\section{Introduction}

Dacryocystitis is an inflammation of the lacrimal sac, which usually occurs because of obstruction of the nasolacrimal duct. ${ }^{1}$ The obstruction may be an idiopathic inflammatory stenosis (primary acquired nasolacrimal duct obstruction $)^{2}$ or may be secondary to trauma, infection, inflammation, neoplasm, or mechanical obstruction (secondary acquired lacrimal drainage obstruction). ${ }^{3}$ Obstruction of the nasolacrimal duct leading to stagnation of tears in a pathologically closed lacrimal drainage system can result in dacryocystitis. ${ }^{1}$

The microbiology of dacryocystitis may differ in acute and chronic infections. Acute dacryocystitis is often caused by Gram-negative rods. ${ }^{1,4}$ In chronic dacryocystitis, mixed bacterial isolates are more commonly found with the predominance of Streptococcus pneumoniae and Staphylococcus spp. ${ }^{1,5}$ Fungal infections caused by Candida albicans and Aspergillus spp occur infrequently. ${ }^{1}$ During the
${ }^{1}$ Department of

Microbiology, Microbiology Research Centre, Aravind Eye Hospital and Postgraduate Institute of Ophthalmology, Tirunelveli, Tamil Nadu, India

${ }^{2}$ Department of Cornea and Refractive Surgery, Cornea Service, Aravind Eye Hospital and Postgraduate Institute of Ophthalmology, Tirunelveli, Tamil Nadu, India

${ }^{3}$ Department of Orbit and Oculoplasty, Aravind Eye Hospital and Postgraduate Institute of Ophthalmology, Tirunelveli, Tamil Nadu, India

Correspondence: MJ Bharathi, Department of Microbiology, Microbiology Research Centre, Aravind Eye Hospital and Postgraduate Institute of Ophthalmology, Tirunelveli, Tamil Nadu 627 001, India Tel: + 910462 2337103; Fax: + 9104622331633 . E-mail: jayahar@ tvl.aravind.org

Received: 4 December 2006 Accepted in revised form: 1 June 2007 Published online: 29 June 2007 
past 20 years, there have been only a few studies on the bacteriology of chronic dacryocystitis. According to them, coagulase-negative staphylococci (CoNS) and Staphylococcus aureus are the most frequently isolated organisms in lacrimal sac infections. ${ }^{5-8}$

There are distinct patterns of geographical variation in terms of aetiology according to the local climate in infective keratitis ${ }^{9}$ and also in microbial conjunctivitis. ${ }^{10}$ Hence, an understating of the region-wise aetiological agents is important in the management of these diseases. The purpose of this study was to identify the bacterial aetiology and to determine the in vitro antibacterial susceptibility and resistance of bacterial pathogens to commonly used antibacterial agents, and an attempt was also made to compare the spectrum of bacterial pathogens and their susceptibility in both acute and chronic dacryocystitis.

\section{Materials and methods}

This retrospective analysis included patients with acute and chronic dacryocystitis who underwent microbiological evaluation presenting between January 2000 and December 2005. Patients were examined on the slit-lamp biomicroscope by a group of ophthalmologists, and cases of dacryocystitis were identified and categorized as acute or chronic, based on their signs and symptoms. ${ }^{1,11}$ Acute dacryocystitis was diagnosed in patients with exquisite pain, redness, and swelling in the tear sac area, tearing or discharge in conjunctiva, and tender swelling over the lacrimal sac region. Chronic dacryocystitis was diagnosed in patients with persistent epiphora and regurgitation of mucoid or mucopurulent material on pressure over the sac area or regurgitation of mucoid or mucopurulent discharge on irrigation of the lacrimal drainage system. ${ }^{1,5,11}$

Specimens for microbiological analysis were obtained by wiping a broth-moistened swab across the lower conjunctival cul-de-sac and also from everted punta by applying pressure over the lacrimal sac area. Surgically excised lacrimal sacs were collected and were also subjected to microbiological analysis. In cases of acute dacryocystitis, along with conjunctival swab, pus discharge following spontaneous bursting of abscess and/or following incision and drainage was also taken. ${ }^{1,11}$ In cases of chronic dacryocystitis, those cases with mucoid or mucopurulent discharge on syringing of the lacrimal sac or having mucocele or pyocele were advised surgery. In those undergoing dacryocystectomy, the sacs were collected intraoperatively and subjected to microbiological examination. Since some cases did not have regurgitation of mucus or mucopurulent discharge or pus on pressure on the lacrimal sac area, preoperative samples could not be taken (eg, encysted mucocele and encysted pyocele cases in which there was insufficient material). Children less than 5 years of age were excluded from this study. All cases of pseudoepiphora and epiphora caused by diagnoses other than nasolacrimal duct obstruction were also excluded from this study.

The material obtained was initially inoculated directly onto the surface of the solid media as sheep's blood agar, chocolate agar, and Sabouraud's dextrose agar and also inoculated into the depth of liquid media as brain heart infusion broth and thioglycollate medium. The material obtained was also smeared onto clean, sterile labeled glass slides for $10 \%$ potassium hydroxide wet mount, Gram stain, Giemsa stain, Ziehl-Neelsen acid-fast stain, and Kinyoun's acid-fast stain. All inoculated media were incubated aerobically. The inoculated Sabouraud's dextrose agar was incubated at $27^{\circ} \mathrm{C}$, examined daily, and discarded at 3 weeks if no growth was seen. The inoculated blood agar, chocolate agar, thioglycollate broth, brain-heart infusion broth were incubated at $37^{\circ} \mathrm{C}$, examined daily, and discarded at 7 days if growth was not seen. Microbial cultures were considered significant if growth of the same organism was demonstrated on more than one solid-phase medium, and/or if there was confluent growth at the site of inoculation on one solid medium, and/or if growth of one medium was consistent with direct microscopy findings (ie, appropriate staining and morphology with Gram stain), and/or if the same organism was grown from more than one specimen. ${ }^{1,11,12}$

The specific identification of bacterial isolates were performed based on microscopic morphology, staining characteristics, and biochemical properties using standard laboratory criteria. ${ }^{13}$ Standardized bacterial inoculum for susceptibility testing was prepared from 4-5 well-isolated colonies of the same morphological type in $5 \mathrm{ml}$ of a suitable broth medium (brain-heart infusion broth, or tryptone soya broth, or peptone water). The broth culture was then allowed to incubate at $37^{\circ} \mathrm{C}$ until a slightly visible turbidity appeared (usually $2-5 \mathrm{~h}$ ), and the turbidity of the inoculum was compared with that resulting from mixing $0.5 \mathrm{ml}$ of $1.75 \%$ barium chloride and $99.5 \mathrm{ml}$ of $0.36 \mathrm{~N}$ sulfuric acid. Standardized bacterial inoculum was inoculated on the MuellerHinton agar using a sterile, non-toxic swab by evenly spreading in three directions over the entire surface of the agar plate to obtain a uniform inoculum. Defibrinated sterile sheep blood (5-10\% v/v) was added for testing Streptococci and other fastidious bacteria. The inoculated plates were then allowed to dry for 3-5 min. The antibacterial impregnated discs were applied with a gap of $24 \mathrm{~mm}$ between them and the plates were incubated at $37^{\circ} \mathrm{C}$ within $15 \mathrm{~min}$ after applying these discs.

Antibacterial discs (obtained from Hi-media Laboratories 
Pvt Ltd, Mumbai, India) were consistently tested for efficacy against standard American Type Culture Collection (ATCC) bacteria (S. aureus ATCC 25923, S. pneumoniae ATCC 49619, Haemophilus influenzae ATCC 49241, Pseudomonas aeruginosa ATCC 27853, Escherichia coli ATCC 25922) as a general quality control laboratory procedure. After 16-18 h of incubation, the plates were examined and the diameter of the zones of complete inhibition was measured by a ruler. When blood agar was tested, the susceptibility was measured by measuring the area where haemolysis did not occur. ${ }^{14,15}$ The zone diameter for individual antimicrobial agent was translated into sensitivity and resistant categories by referring to an interpretative chart as per the recommendation of the NCCLS.

Statistical software (STATA 8.1, Stata Corporation, Texas) was used for statistical analysis. The values are presented as frequencies and percentages. Significant differences between two groups (acute dacryocystitis and chronic dacryocystitis) were studied using Pearson's $\chi^{2}$ test, and $P$-value $<0.05$ was considered to be statistically significant.

\section{Results}

A total of 1891 patients with dacryocystitis were referred to the department of microbiology for evaluation, of which $566(29.9 \%)$ patients had acute onset and the remaining 1325 (70.1\%) had chronic onset dacryocystitis. Single eye was infected in all 1891 patients. Of 1891 eyes, $1518(80.3 \%)$ had pure bacterial growth and the remaining $373(19.7 \%)$ had no growth. The percentage of culture-positivity was found to be higher among eyes with chronic dacryocystitis $(90 \%)$ than among eyes with acute dacryocystitis (57.4\%), and the difference was statistically significant $(P<0.0001)$ (Table 1$)$.

Of 1891 patients, $1505(79.6 \%)$ were females and 386 $(20.4 \%)$ were males. Female predominance was seen among both acute $(433$ of $566 ; 76.5 \%)$ and chronic infections (1072 of 1325; 80.9\%), and females were significantly higher among chronic dacryocystitis $(P=0.034)$. Out of 1891 patients, $268(14.2 \%)$ were between the age of 5 and 30 years (135 (23.6\%) of 566 patients with acute infection and $133(10 \%)$ of 1325 patients with chronic infection), 1304 (69\%) were between the age of 31 and 60 years (366 (64.7\%) of 566 acute infection and $938(70.8 \%)$ of 1325 chronic infection) and the remaining $319(16.9 \%)$ were between the age of 61 and 80 years $(65$ (11.5\%) of 566 acute infection and 254 (19.2\%) of 1325 chronic infection). However, patients above the age of 30 years (1192 of 1325; 90\%) were significantly $(P<0.0001)$ more than patients below 31 years $(133$ of $1325 ; 10 \%)$ among chronic dacryocystitis.
Minor discharges from 248 eyes, mucopurulent discharges from 91 eyes, pus of spontaneous bursting abscess from 64 eyes, and pus of incision drainage from 163 eyes were collected from a total of 566 acute cases, of which 325 (57.4\%) were found to be culture positive. Both lacrimal sac content and mucous discharge from 676 eyes and lacrimal sac content alone from 649 eyes were collected from a total of 1325 chronic cases, of which 1193 (90\%) were found to be culture positive; these results are summarized in Table 2. A total of 337 bacterial isolates from 325 eyes with acute dacryocystitis and 1275 bacterial isolates from 1193 eyes with chronic dacryocystitis were isolated, and thus a total of 1612 bacterial isolates were recovered. Of the 1518 dacryocystitis eyes that yielded only bacterial growth, 1424 (93.8\%) (313 eyes with acute infection and 1111 eyes with chronic infection) eyes had single species of bacterial isolates and the remaining 94 (6.2\%) (12 eyes with acute infection and 82 eyes with chronic infection) eyes had two species of bacterial isolates. The predominant bacterial pathogen isolated from eyes with acute dacryocystitis was S. aureus (75 of 337; 22.3\%) followed by Pseudomonas spp (71 of 337; 21.1\%) and $S$. pneumoniae (54 of 337; 16\%), while in cases of chronic dacryocystitis, CoNS (563 of 1275; 44.2\%) followed by $S$. aureus (138 of $1275 ; 10.8 \%$ ) and S. pneumoniae (111 of 1275; $8.7 \%$ ) were found to be the predominant bacterial pathogens (Table 2).

The highest percentage of bacterial isolates were susceptible to gatifloxacin (632 of $655 ; 96.5 \%)$, ofloxacin (621 of $655 ; 94.8 \%$ ), and amikacin (1468 of 1612; 91.1\%) (Table 3), while the highest percentage of bacterial isolates were resistant to norfloxacin (769 of 1612; 47.7\%), tobramycin (765 of 1612;47.5\%), and gentamicin (665 of $1612 ; 41.3 \%)$. Of all antibacterial agents tested, gatifloxacin and ofloxacin showed lowest percentage of resistance to all categories of bacterial species recovered from both acute and chronic infections of the lacrimal apparatus. The percentage of resistance of bacterial isolates recovered from chronic infections to gentamicin (582 of $1275 ; 45.7 \%$ ), tobramycin (647 of $1275 ; 50.8 \%$ ), norfloxacin ( 646 of $1275 ; 50.7 \%$ ), and ciprofloxacin (387 of $1275 ; 30.4 \%$ ) was found to be higher than the percentage of resistance of bacterial isolates recovered from acute infection to gentamicin (83 of $337 ; 24.6 \%)$, tobramycin (118 of $337 ; 35 \%)$, norfloxacin $(123$ of $337 ; 36.5 \%)$, and ciprofloxacin $(67$ of $337 ; 19.9 \%)$. The percentage of the resistance of bacterial isolates (both Gram-positive cocci and Gram-negative bacilli) recovered from acute infection was less than that of the isolates of the same organisms recovered from chronic infections.

Out of 1891 patients, $1473(77.9 \%)$ had received medical therapy before initial presentation at this institute, of which 253 (17.2\%) had acute infection and 
the remaining 1220 (82.8\%) had chronic dacryocystitis. The number of patients who had prior medical therapy was significantly higher among patients with chronic dacryocystitis $(92 \%)$ than those with acute dacryocystitis $(44.7 \%)(P<0.0001)$. Of 1473 patients who had prior medical therapy, $1381(93.75 \%)$ had received topical antibiotics (gentamicin, tobramycin, norfloxacin, or ciprofloxacin) (225 of 566 acute infection and 1156 of 1325 chronic infection) and $92(6.3 \%)$ had received both topical and oral antibiotics (28 of 566 acute infection and 64 of 1325 chronic infection).

\section{Discussion}

The most common infection of the lacrimal apparatus is dacryocystitis. The lacrimal excretory system is prone to infection and inflammation for various reasons. This mucus membrane-lined tract is contagious with two surfaces (conjunctival and nasal mucosal) that are normally colonized with bacteria. The functional purpose of the lacrimal excretory system is to drain tears from the eye into the nasal cavity. Obstruction of the nasolacrimal duct from whatever source results in stasis with the accumulation of tears, desquamated cells, and mucoid secretions superior to the obstruction. This creates a fertile environment for secondary bacterial infection. ${ }^{1}$ Obstructed nasolacrimal duct may occur in any age group. Congenital blockage occurs in 3-6\% of term infants. ${ }^{16}$ In most of these cases, the nasal end of the duct is blocked by epithelial debris or an imperforate mucosal membrane resulting from incomplete canalization of the embryonic duct. ${ }^{16}$ Primary and secondary acquired nasolacrimal duct obstruction usually occurs mainly in middle-aged or older people with a 3:1 female preponderance due to obliteration of the lumen. ${ }^{2}$ Similarly in this study, patients with age greater than 30 years were significantly more in number in chronic dacryocystitis $(90 \%)$ than those aged less than 31 years $(10 \%)$. The over all female-to-male ratio in this study was $3.9: 1$ and female subjects $(80.9 \%)$ were significantly more in number in chronic dacryocystitis than male subjects (19.1\%).

The spectrum and the proportion of bacterial pathogens as well as antibiotic susceptibility may differ from region to region. In this study, Gram-positive cocci was found in $69.7 \%$ of the isolates, and similarly Coden et $a l^{8}$ and Hartikainen et $a l^{5}$ reported 65 and $69 \%$ of the Gram-positive cocci from patients with dacryocystitis, respectively. The most common organism cultured in this study was Staphylococcus spp, accounting for $50 \%$ of the isolates. Similar incidence was reported by Thicker and Buffam $^{7}(73 \%)$, Huber-Spitzy et al $^{6}(51 \%)$, and Coden et $a l^{8}(49 \%)$. Sainju et $l^{17}$ reported the predominance of $S$. aureus $(34.2 \%)$ in dacryocystitis among southern 
Table 2 Bacterial pathogens recovered from ocular specimens (minor discharge, copious purulent or mucous discharge, bursting abscess, incision drainage and/ or lacrimal sac contents) obtained from 1518 eyes with dacryocystitis in south India

\begin{tabular}{|c|c|c|c|c|c|c|c|c|c|c|}
\hline \multirow{2}{*}{$\begin{array}{l}\text { Sl. } \\
\text { no. }\end{array}$} & \multirow{2}{*}{$\begin{array}{l}\text { Name of the } \\
\text { bacterial } \\
\text { species } \\
\text { recovered }\end{array}$} & \multirow{2}{*}{$\begin{array}{c}\text { Total no. of } \\
\text { bacterial } \\
\text { species recovered } \\
\text { from patients } \\
\text { with } \\
\text { dacryocystitis }\end{array}$} & \multicolumn{5}{|c|}{ Patients with acute dacryocystitis } & \multicolumn{3}{|c|}{ Patients with chronic dacryocystitis } \\
\hline & & & $\begin{array}{l}\text { Total no. of } \\
\text { isolates } \\
\text { recovered } \\
\text { from eyes with } \\
\text { acute infection } \\
(\%)\end{array}$ & $\begin{array}{l}\text { No. of bacterial } \\
\text { isolates } \\
\text { recovered } \\
\text { from minor } \\
\text { discharge } \\
\text { alone }(\%)\end{array}$ & $\begin{array}{l}\text { No. of } \\
\text { bacterial } \\
\text { isolates } \\
\text { recovered } \\
\text { from copious } \\
\text { purulent or } \\
\text { mucous } \\
\text { discharge } \\
\text { alone (\%) }\end{array}$ & $\begin{array}{l}\text { No. of } \\
\text { bacterial } \\
\text { isolates } \\
\text { recovered } \\
\text { from bursting } \\
\text { abscess alone } \\
(\%)\end{array}$ & $\begin{array}{l}\text { No. of } \\
\text { bacterial } \\
\text { isolates } \\
\text { recovered } \\
\text { from incision } \\
\text { drainage alone } \\
(\%)\end{array}$ & $\begin{array}{l}\text { Total no. of isolates } \\
\text { recovered from } \\
\text { eyes with chronic } \\
\text { infection (\%) }\end{array}$ & $\begin{array}{l}\text { No. of bacterial } \\
\text { isolates recovered } \\
\text { from both } \\
\text { copious purulent } \\
\text { or mucous } \\
\text { discharge and } \\
\text { lacrimal sac } \\
\text { content (\%) }\end{array}$ & $\begin{array}{c}\text { No. of } \\
\text { bacterial } \\
\text { isolates recovered } \\
\text { from lacrimal } \\
\text { sac content } \\
\text { alone }(\%)\end{array}$ \\
\hline \multirow[t]{6}{*}{1} & Total Gram-positive cocci & $1123(69.7)$ & 175 & 13 & 43 & 18 & 101 & 948 & $349(36.8)$ & $599(63.2)$ \\
\hline & $\begin{array}{l}\text { Staphylococcus aureus } \\
\text { Coagulase negative }\end{array}$ & 213 & 75 & 9 & 19 & 12 & 35 & 138 & 39 & $99(71.7)$ \\
\hline & Staphylococci & 594 & 31 & 3 & 6 & 1 & 21 & 563 & $261(46.4)$ & $302(53.6)$ \\
\hline & Micrococcus spp & 11 & 2 & 0 & 0 & 0 & 2 & 9 & 2 & 7 \\
\hline & Streptococcus pneumoniae & 165 & 54 & 0 & 16 & 4 & 34 & 111 & 28 & $83(74.8)$ \\
\hline & Other streptococcus species & 140 & 13 & 1 & 2 & 1 & 9 & 127 & 19 & $108(85)$ \\
\hline \multirow[t]{2}{*}{2} & Total Gram-positive bacilli & $19(1.2)$ & 0 & 0 & 0 & 0 & 0 & 19 & $11(57.9)$ & $8(42.1)$ \\
\hline & Corynebacterium spp & 19 & 0 & 0 & 0 & 0 & 0 & 19 & 11 & 8 \\
\hline \multirow[t]{2}{*}{3} & Total Gram-negative cocci and coccobacilli & $6(0.4)$ & 0 & 0 & 0 & 0 & 0 & 6 & $1(16.7)$ & $5(83.3)$ \\
\hline & Moraxella spp & 6 & 0 & 0 & 0 & 0 & 0 & 6 & 1 & 5 \\
\hline \multirow[t]{10}{*}{4} & Total Gram-negative bacilli & $464(28.8)$ & 162 & 24 & 34 & 46 & 58 & 302 & $279(92.4)$ & $23(7.6)$ \\
\hline & Pseudomonas spp & 162 & 71 & 10 & 15 & 21 & 25 & 91 & 91 & 0 \\
\hline & Escherichia coli & 76 & 23 & 3 & 4 & 8 & 8 & 53 & 53 & 0 \\
\hline & Proteus spp & 47 & 21 & 4 & 3 & 4 & 10 & 26 & 26 & 0 \\
\hline & Haemophilus spp & 48 & 21 & 1 & 4 & 5 & 11 & 27 & 9 & 18 \\
\hline & Enterobacter spp & 37 & 6 & 1 & 0 & 3 & 2 & 31 & 31 & 0 \\
\hline & Acinetobacter spp & 27 & 3 & 0 & 0 & 2 & 1 & 24 & 21 & 3 \\
\hline & Citrobacter spp & 14 & 2 & 0 & 0 & 1 & 1 & 12 & 12 & 0 \\
\hline & Klebsiella spp & 53 & 15 & 5 & 8 & 2 & 0 & 38 & 36 & 2 \\
\hline & Total & $1612(100)$ & $337 / 1612(20.9)$ & $37(2.3)$ & $77(4.8)$ & $64(4)$ & $159(9.9)$ & $1275 / 1612(79.1)$ & $640(39.7)$ & $635(39.4)$ \\
\hline
\end{tabular}


Australian population. S. pneumoniae represented $10 \%$ of the isolates in this study, which is higher than HuberSpitzy et $a l^{6}(2 \%)$, Coden et $a l^{8}(2.3 \%)$, and Hartikainen et $a l^{5}(5 \%)$. Gram-negative bacilli represented $29 \%$ of the isolates, the most frequently isolated species being Pseudomonas spp (10\%) followed by E. coli (4.7\%). Similarly, Coden et $a l^{8}$ observed Gram-negative organisms in $27 \%$ of all isolates, including P. aeruginosa in 9\%. Huber-Spitzy et $a l^{6}$ reported Gram-negative organisms accounting for $26 \%$ of isolates, the most frequent species being E. coli (12\%). Briscoe et al ${ }^{18}$ recovered $61 \%$ of the Gram-negative bacilli with predominance of $P$. aeruginosa (22\%) from patients with purulent dacryocystitis in Israel. In contrast, Hartikainen et $a l^{5}$ reported $H$. influenzae as the most frequent Gramnegative isolates $(4 \%)$.

The prevalence of bacterial pathogens responsible for acute dacryocystitis and chronic dacryocystitis differed from each other in this study. In acute dacryocystitis, $S$. aureus $(22.3 \%)$ and Pseudomonas spp (21.1\%) were isolated as the predominant bacterial pathogens, whereas in chronic dacryocystitis, CoNS was found to be the predominant bacterial pathogen followed by $S$. aureus and S. pneumoniae, accounting for $44.2,10.8$, and $8.7 \%$ of the isolates, respectively. Sun et $a l^{19}$ have studied the microbiology of chronic dacryocystitis in China. They reported that Staphylococcus species constituted 34.5\% of isolates in their series. The spectrum of aerobic and facultative organisms recovered in this study is also consistent with results reported by Brook and Frazier ${ }^{20}$ in USA, as Staphylococcus, Pseudomonas, and Streptococcus species were also the predominant pathogens. In addition, the prevalence of $S$. pneumoniae was found to be higher in chronic cases $(67.3 \%)$ than in acute cases $(32.7 \%)$. An analysis on the spectrum of bacterial pathogens causing acute and chronic infections of dacryocystitis shows that highly virulent pathogens such as S. aureus and Pseudomonas spp are responsible for the development of dacryocystitis in higher frequency as acute onset than as chronic onset. While less virulent bacteria, CoNS are responsible for development of dacryocystitis in higher frequency as chronic onset.

The analysis of the in vitro susceptibility shows that the first generation cephalosporin, cefazolin, has a higher efficacy against Gram-positive isolates when compared with that of other antibacterial agents. Among aminoglycosides, amikacin shows higher effectiveness against both Gram-positive and Gram-negative isolates. The possible explanation for higher susceptibility is that cefazolin and amikacin are not frequently used in our community. Among the fluoroquinolones, the ciprofloxacin and norfloxacin show decreased efficacy against all pathogens compared with gatifloxacin and ofloxacin, which show higher efficacy against all pathogens. Frequent and routine use of ciprofloxacin and norfloxacin for all bacterial ocular infections in our population has decreased susceptibility to ciprofloxacin and norfloxacin.

The analysis of the in vitro resistance pattern shows variation in the resistance of isolates of the same bacteria recovered from acute and chronic dacryocystitis. Bacteria recovered from chronic dacryocystitis show higher percentage of resistance than those recovered from acute dacryocystitis. Our data revealed that the emergence of drug-resistance takes place among bacterial isolates recovered from chronic cases. The reason for the emergence of resistance is not completely understood, although prophylactic use of antibiotics, cycling, or using different antibiotics for different ocular infections, chronic antibiotic therapy for non-infectious ocular diseases, and prolonged unnecessary therapy before (several days) and after (weeks) surgery are some of the factors that increased resistance. ${ }^{21,22}$ Bacterial flora is abundant at the eyelid margin, and the setting is conducive to a possible spontaneous mutation that can cause antibiotics resistance.

Compared to other developing countries, south India has a high rate of antibiotic use. ${ }^{23}$ In our study, $77.9 \%$ of the patients had used topical antibiotics before presentation, of which $92 \%$ of the cases were chronic dacryocystitis and $44.7 \%$ were acute dacryocystitis, and the difference was statistically significant $(P<0.0001)$. Hence, our data suggest that the use of topical antibiotics can clearly cause the risk of developing bacterial resistance among bacterial flora in lacrimal apparatus. The use of broad-spectrum antibiotics is another risk factor for developing bacterial resistant. ${ }^{21}$ The overall comparative analysis of in vitro resistance of bacterial isolates from acute and chronic infections shows that the narrow-spectrum or fortified antibiotics, cefazolin and vancomycin, have retained Gram-positive bacterial effectiveness over the year, which probably also existed previously. ${ }^{24}$ All patients who received medical therapy prior presentation had instilled broad-spectrum antibiotics; gentamicin, tobramycin, ciprofloxacin, and norfloxacin being the most common ones. Our data revealed that the use of broad-spectrum antibiotics produced increasing resistant profiles among bacterial isolates from chronic dacryocystitis than in bacterial isolates from acute infection.

It must be noted that in this present study, all inoculated culture media were incubated at aerobic condition. Thus, the spectrum of bacterial pathogens recovered from eyes with acute and chronic dacryocystitis shows the complete profile of aerobic bacteriology. Although the bacterial aetiology of dacryocystitis includes a large spectrum of bacterial species belonging to both aerobic and anaerobic group, 
Table 3 In vitro antibacterial susceptibilities of bacterial isolates recovered from ocular specimens (minor discharge, copious purulent or mucous discharge, bursting abscess, incision drainage, and/ or lacrimal sac contents) obtained from eyes with dacryocystitis in south India

\begin{tabular}{|c|c|c|c|c|c|c|c|c|c|c|c|c|c|c|}
\hline \multirow[b]{2}{*}{$\begin{array}{l}\text { Sl. } \\
\text { No. }\end{array}$} & \multirow[b]{2}{*}{$\begin{array}{l}\text { Name of the bacterial } \\
\text { species recovered }\end{array}$} & \multicolumn{13}{|c|}{ Number of the susceptible bacterial isolates / number of tested isolates (\% of the susceptible isolates) against common antibacterial agents by disc diffusion method } \\
\hline & & Cefazolin & Vancomycin & Chloramphenicol & l Cephotaxime & Ceftazidime & Gentamicin & Amikacin & Tobramycin & Ciprofloxacin & Norfloxacin & Gatifloxacin & Ofloxacin & Moxifloxacin \\
\hline \multirow[t]{9}{*}{1} & Total Gram-positive cocci & 1058/1123 & $749 / 1123$ & $875 / 1123$ & $682 / 1123$ & $674 / 1123$ & $626 / 1123$ & $996 / 1123$ & $576 / 1123$ & $786 / 1123$ & $559 / 1123$ & $434 / 450$ & $425 / 450$ & $404 / 450$ \\
\hline & & (94.2) & (66.7) & (77.9) & $(60.7)$ & (60) & $(55.7)$ & $(88.7)$ & (51.3) & (70) & $(49.8)$ & (96.4) & (94.4) & $(89.8)$ \\
\hline & Staphylococcus aureus & $\begin{array}{l}201 / 213 \\
(94.4)\end{array}$ & $\begin{array}{l}139 / 213 \\
(65.3)\end{array}$ & $\begin{array}{l}170 / 213 \\
(79.8)\end{array}$ & $\begin{array}{l}119 / 213 \\
(55.9)\end{array}$ & $\begin{array}{l}112 / 213 \\
(52.6)\end{array}$ & $\begin{array}{l}111 / 213 \\
(52.1)\end{array}$ & $\begin{array}{l}189 / 213 \\
(88.7)\end{array}$ & $\begin{array}{l}101 / 213 \\
(47.4)\end{array}$ & $\begin{array}{l}152 / 213 \\
(71.4)\end{array}$ & $\begin{array}{l}101 / 213 \\
(47.4)\end{array}$ & $\begin{array}{l}82 / 85 \\
(96.7)\end{array}$ & $\begin{array}{l}79 / 85 \\
(92.9)\end{array}$ & $\begin{array}{l}76 / 85 \\
(89.4)\end{array}$ \\
\hline & Coagulase-negative & $555 / 594$ & $393 / 594$ & $473 / 594$ & $365 / 594$ & $369 / 594$ & $310 / 594$ & $521 / 594$ & $299 / 594$ & $406 / 594$ & $312 / 594$ & $233 / 240$ & $230 / 240$ & $221 / 240$ \\
\hline & staphylococci & (93.4) & $(66.2)$ & (79.6) & (61.5) & (62.2) & (52.2) & (87.7) & (50.3) & (68.4) & (52.5) & (97.1) & (95.8) & (92.1) \\
\hline & Micrococcus spp & $11 / 11(100)$ & $\begin{array}{l}8 / 11 \\
(72.7)\end{array}$ & $8 / 11(72.7)$ & $6 / 11(54.6)$ & 6/11 (54.6) & $\begin{array}{l}4 / 11 \\
(36.4)\end{array}$ & $\begin{array}{l}10 / 11 \\
(90.9)\end{array}$ & 6/11 (54.6) & $\begin{array}{l}9 / 11 \\
(81.8)\end{array}$ & $6 / 11(54.6)$ & $3 / 3(100)$ & $3 / 3(100)$ & $3 / 3(100)$ \\
\hline & Streptococcus pneumoniae & $\begin{array}{l}159 / 165 \\
(96.4)\end{array}$ & $\begin{array}{l}110 / 165 \\
(66.7)\end{array}$ & $\begin{array}{l}115 / 165 \\
(69.7)\end{array}$ & $\begin{array}{l}91 / 165 \\
(55.2)\end{array}$ & $\begin{array}{l}88 / 165 \\
(53.3)\end{array}$ & $\begin{array}{l}95 / 165 \\
(57.6)\end{array}$ & $\begin{array}{l}146 / 165 \\
(88.5)\end{array}$ & $\begin{array}{l}89 / 165 \\
(53.9)\end{array}$ & $\begin{array}{l}109 / 165 \\
(66.1)\end{array}$ & $61 / 165(37)$ & $\begin{array}{l}62 / 66 \\
(93.9)\end{array}$ & $\begin{array}{l}61 / 66 \\
(92.4)\end{array}$ & $\begin{array}{l}55 / 66 \\
(83.3)\end{array}$ \\
\hline & Other streptococci & $132 / 140$ & $99 / 140$ & $109 / 140$ & $101 / 140$ & $99 / 140$ & $106 / 140$ & $130 / 140$ & $81 / 140$ & $110 / 140$ & $79 / 140(56.4)$ & $54 / 56$ & $52 / 56$ & $49 / 56$ \\
\hline & & (94.3) & (70.7) & $(77.9)$ & $(72.1)$ & $(70.7)$ & (75.7) & (93) & (57.9) & $(78.8)$ & & (96.4) & $(92.9)$ & (87.5) \\
\hline \multirow[t]{2}{*}{2} & Total Gram-positive bacilli & $17 / 19(89.5)$ & $\begin{array}{l}11 / 19 \\
(57.9)\end{array}$ & $12 / 19(63.2)$ & 9/19 (47.4) & $9 / 19(47.4)$ & $\begin{array}{l}8 / 19 \\
(42.1)\end{array}$ & $\begin{array}{l}16 / 19 \\
(84.2)\end{array}$ & $8 / 19(42.1)$ & $\begin{array}{l}12 / 19 \\
(63.2)\end{array}$ & $8 / 19(42.1)$ & $8 / 8(100)$ & $8 / 8(100)$ & $7 / 8(87.5)$ \\
\hline & Corynebacterium spp & $17 / 19(89.5)$ & $\begin{array}{l}11 / 19 \\
(57.9)\end{array}$ & $12 / 19(63.2)$ & 9/19 (47.4) & 9/19 (47.4) & $\begin{array}{l}8 / 19 \\
(42.1)\end{array}$ & $\begin{array}{l}16 / 19 \\
(84.2)\end{array}$ & $8 / 19(42.1)$ & $\begin{array}{l}12 / 19 \\
(63.2)\end{array}$ & 8/19 (42.1) & $8 / 8(100)$ & $8 / 8(100)$ & $7 / 8(87.5)$ \\
\hline \multirow[t]{3}{*}{3} & Total Gram-negative cocci and & $2 / 6(33.3)$ & $2 / 6(33.3)$ & $5 / 6(83.3)$ & $5 / 6(83.3)$ & $5 / 6(83.3)$ & $5 / 6(83.3)$ & $5 / 6(83.3)$ & $4 / 6(66.7)$ & $5 / 6(83.3)$ & $4 / 6(66.7)$ & $2 / 2(100)$ & $2 / 2(100)$ & $2 / 2(100)$ \\
\hline & coccobacilli & & & & & & & & & & & & & \\
\hline & Moraxella spp & $2 / 6(33.3)$ & 2/6 (33.3) & $5 / 6(83.33)$ & $5 / 6(83.3)$ & $5 / 6(83.3)$ & $5 / 6(83.3)$ & $5 / 6(83.3)$ & $4 / 6(66.7)$ & $5 / 6(83.3)$ & $4 / 6(66.67)$ & $2 / 2(100)$ & $2 / 2(100)$ & $2 / 2(100)$ \\
\hline \multirow[t]{19}{*}{4} & Total Gram-negative bacilli & $21 / 464$ & $89 / 464$ & $173 / 464$ & $334 / 464$ & $324 / 464$ & $305 / 464$ & $451 / 464$ & $259 / 464$ & $355 / 464$ & $272 / 464$ & $188 / 195$ & 186/195 & $166 / 195$ \\
\hline & & (4.5) & (19.2) & (37.3) & (72) & (69.8) & (65.7) & (97.2) & (55.8) & $(76.5$ & (58.6) & (96.4) & (95.4) & (85.2) \\
\hline & Pseudomonas spp & $0 / 162(0)$ & $23 / 162$ & $49 / 162$ & $116 / 162$ & $115 / 162$ & $109 / 162$ & $159 / 162$ & $90 / 162$ & $126 / 162$ & $93 / 162$ & $66 / 67$ & $65 / 67$ & $59 / 67$ \\
\hline & & & $(14.2)$ & (30.3) & (81.7) & (71) & $(67.3)$ & (98.2) & (55.6) & (77.8) & $(57.4)$ & (98.5) & (97) & (88.1) \\
\hline & Escherichia coli & $7 / 76(9.2)$ & $15 / 76$ & $26 / 76$ & $54 / 76$ & $54 / 76$ & $51 / 76$ & $73 / 76$ & $47 / 76$ & $59 / 76$ & $49 / 76$ & $31 / 33$ & $31 / 33$ & $29 / 33$ \\
\hline & & & (19.7) & (34.2) & (71.1) & (71.1) & (67.1) & (96.1) & (61.8) & (77.6) & (64.5) & (93.9) & (93.9) & (87.9) \\
\hline & Proteus spp & $0 / 47(0)$ & $9 / 47$ & $13 / 47$ & $33 / 47$ & $31 / 47$ & $31 / 47$ & $45 / 47$ & $25 / 47$ & $36 / 47$ & $26 / 47$ & $19 / 21$ & $19 / 21$ & $18 / 21$ \\
\hline & & & (19.2) & (27.7) & (70.2) & (66) & (66) & (95.7) & (53.2) & (76.6) & (55.3) & (90.5) & (90.5) & (85.7) \\
\hline & Haemophilus spp & 6/48 (12.5) & $8 / 48$ & $16 / 48$ & $33 / 48$ & $29 / 48$ & $31 / 48$ & $47 / 48$ & $27 / 48$ & $35 / 48$ & $28 / 48$ & $22 / 22$ & $21 / 22$ & $17 / 22$ \\
\hline & & & (16.7) & & $(68.8)$ & (60.4) & (64.6) & (97.9) & (56.3) & (72.9) & (58.3) & (100) & (95.5) & (77.3) \\
\hline & Enterobacter spp & 4/37 (10.8) & $9 / 37$ & $21 / 37(56.8)$ & $27 / 37$ & $27 / 37$ & $22 / 37$ & $35 / 37$ & $18 / 37$ & $25 / 37$ & $20 / 37$ & $16 / 16$ & $16 / 16$ & $13 / 16$ \\
\hline & & & (24.3) & & (73) & (73) & (59.5) & (94.6) & $(48.7)$ & (67.6) & (54.1) & (100) & (100) & (81.3) \\
\hline & Acinetobacter spp & $0 / 27(0)$ & $11 / 27$ & $23 / 27$ (85.2) & $19 / 27$ & $19 / 27$ & $16 / 27$ & $26 / 27$ & $13 / 27$ & $21 / 27$ & $15 / 27$ & $9 / 9$ & 9/9 (100) & $7 / 9$ \\
\hline & & & (40.7) & & (70.4) & (70 4) & (59.3) & (96.3) & $(48.2)$ & $(77.8)$ & (55.6) & (100) & & (77.8) \\
\hline & Citrobacter spp & 4/14 (28.6) & $5 / 14$ & 9/14 (64.3) & $10 / 14$ & $9 / 14$ & $8 / 14$ & $14 / 14$ & $8 / 14$ & $11 / 14$ & $8 / 14$ & $6 / 6$ & 6/6 (100) & $6 / 6$ \\
\hline & & & (35.7) & & (71.4) & (64.3) & (57.1) & (100) & (57.1) & (78.6) & (57.1) & (100) & & (100) \\
\hline & Klebsiella spp & $0 / 53(0)$ & $9 / 53$ & $16 / 53(30.2)$ & $42 / 53$ & $40 / 53$ & $37 / 53$ & $52 / 53$ & $31 / 53$ & $42 / 53$ & $33 / 53$ & $19 / 21$ & $19 / 21$ & $17 / 21$ \\
\hline & & & (17) & & (79.3) & (75.5) & (69.8) & (98.1) & (58.5) & (79.3) & (62.3) & (90.5) & (90.5) & $(81)$ \\
\hline & Total & $\begin{array}{l}1098 / 1612 \\
(68.1)\end{array}$ & $\begin{array}{l}851 / 1612 \\
(52.8)\end{array}$ & $\begin{array}{l}1065 / 1612 \\
(66.1)\end{array}$ & $\begin{array}{l}1030 / 1612 \\
(63.9)\end{array}$ & $\begin{array}{l}1012 / 1612 \\
(62.8)\end{array}$ & $\begin{array}{l}944 / 1612 \\
(58.6)\end{array}$ & $\begin{array}{l}1468 / 1612 \\
(91.1)\end{array}$ & $\begin{array}{l}847 / 1612 \\
(52.5)\end{array}$ & $\begin{array}{l}1158 / 1612 \\
(71.8)\end{array}$ & $\begin{array}{l}843 / 1612 \\
(52.3)\end{array}$ & $\begin{array}{l}632 / 655 \\
(96.5)\end{array}$ & $\begin{array}{l}621 / 655 \\
(94.8)\end{array}$ & $\begin{array}{l}579 / 655 \\
(88.4)\end{array}$ \\
\hline
\end{tabular}


the present study highlights the potential importance of only aerobic bacterial pathogens and their susceptibility to commonly used antibacterial agents. The true incidence and the prevalence of bacterial pathogens causing dacryocystitis could not be calculated in our study because only specimen sent to the laboratory or patients referred to microbiology department for microbiological evaluation were included in this study. However, the actual prevalence of aerobic and facultative organisms in dacryocystitis has yet to be retrospectively investigated.

It must also be noted that the conventional KirbyBauer disk diffusion method of in vitro antibacterial susceptibility testing may not directly apply to ocular pathogens, since the ocular antibacterial level achievable by topical administration may be considerably higher than the level attained at the ocular tissue by systemic administration. Indeed, there have been many studies that have reported susceptible and resistant pattern of ocular pathogens with conventional in vitro antibacterial susceptibility testing, and this in vitro susceptible and resistant pattern have been successfully treated in vivo by those antibacterials. These results do provide information that allows a clinician to make rationale-based decisions in choosing a primary treatment regimen, which provide broad coverage for common ocular pathogens.

In conclusion, the proportion of S. aureus and Pseudomonas spp is higher in causing acute dacryocystitis, while CoNS are frequently associated with chronic dacryocystitis. Of all antibacterials tested, gatifloxacin, ofloxacin, and amikacin show greater efficacy against bacterial isolates from dacryocystitis. Bacterial species isolated from chronic dacryocystitis shows higher resistance to broad-spectrum antibiotics than those from acute cases.

\section{References}

1 Iliff NT. Infections of the lacrimal drainage system. In: Peopse JS, Holland GN, Wilhelmus KR (eds). Ocular Infection and Immunity. Mosby: St Louis, MO, 1996, pp 1346-1355.

2 Linberg JV. Disorders of the lower excretory system. In: Milder B, Weil BA (eds). The Lacrimal System. AppletonCentury-Crofts: New York, 1983, pp 1-134.

3 Bartley GB. Acquired lacrimal drainage obstruction: an etiologic classification system, case reports, and a review of the literature. Part 1. Ophthal Plast Reconstr Surg 1992; 8: 237-242.

4 Cahill KV, Burns JA. Management of acute dacryocystitis in adults. Ophthalmic Plast Reconstr Surg 1993; 9: 38.

5 Hartikainen J, Lehtonen OP, Saari KM. Bacteriology of lacrimal duct obstruction in adults. Br J Ophthalmol 1997; 81: 37-40.

6 Huber-Spitzy V, Steinkogler FJ, Huber E, Arocker-Mettinger E, Schiffbänker M. Acquired dacryocystitis: microbiology and conservative therapy. Acta Ophthalmol (Copenh) 1992; 70: 745-749.

7 Thicker JA, Buffam FV. Lacrimal sac, conjunctival, and nasal culture results in dacryocystorhinostomy patients. Ophthal Plast Reconstr Surg 1993; 9: 43-46.

8 Coden DJ, Hornblass A, Haas BD. Clinical bacteriology of dacryocystitis in adults. Ophthal Plast Reconstr Surg 1993; 9: 125-131.

9 Bharathi MJ, Ramakrishnan R, Vasu S, Meenakshi R, Shivkumar C, Palaniappan R. Epidemiology of bacterial keratitis in a referral centre in south India. Indian J Med Microbiol 2003; 21: 239-245.

10 Burd EM. Bacterial keratitis and conjunctivitis: bacteriology. In: Smolin G, Thoft RA (eds). The Cornea: Scientific Foundations and Clinical Practices, 3rd ed. Little, Brown \& Co.: Boston, 1994, pp 115-124.

11 Wilhemus KR, Liesegang TJ, Osato MS, Jones DB. Cumitech 13 A, Laboratory Diagnosis of Ocular Infcetions. American Society for Microbiology: Washington, DC, 1994.

12 Byrne KA, Burd E, Tabbara K, Hyndiuk R (eds). Diagnostic Microbiology and Cytology of the Eye. Butterworth Heinemann: Boston, 1995.

13 Coyle MB, Morello JA, Smith PB. Aerobic bacteria. In: Lennette EH, Balows A, Hausler WJ, shadomy HJ (eds). Manual of Clinical Microbiology. American Society for Microbiology: Washington, DC, 1985 pp 143-411.

14 National Committee for Clinical Laboratory Standards. Performance standards for antimicrobial disk susceptibility tests, 7th ed. Approved standard M2-A7. National Committee for Clinical Laboratory Standards: Villanova, PA, 2000.

15 Barry AL, Thornsberry C. Susceptibility test: Diffusion Test Procedures. In: Lennette EH, Balows A, Hausler WJ, shadomy HJ (eds). Manual of Clinical Microbiology. American Society for Microbiology: Washington DC, 1985 pp 978-987.

16 Kushner BJ. Congenital nasolacrimal system obstruction. Arch Ophthalmol 1982; 100: 697.

17 Sainju R, Franzco AA, shrestha MK, Ruit S. Microbiology of dacryocystitis among adults population in southern Australia. Nepal Med Coll J 2005; 7: 18-20.

18 Briscoe D, Rubowitz A, Assia EI. Changing bacterial isolates and antibiotic sensitivities of purulent dacryocystitis. Orbit 2005; 24: 95-98.

19 Sun X, Liang Q, Luo S, Wang Z, Li R, Jin X. Microbiological analysis of chronic dacryocystitis. Ophthalmic Physiol Opt 2005; 25: 261-263.

20 Brook I, Frazier EH. Aerobic and anaerobic microbiology of dacryocystitis. Am J Ophthalmol 1998; 125: 552-554.

21 Kowalski RP, Karenchak LM, Romanowski EG. Infectious disease: changing antibiotics susceptibility. Ophthalmol Clin North Am 2003; 16: 1-9.

22 Gaynor BD, Chidambaram JD, Cevallos V, Miao Y, Miller K, Jha HC et al. Topical ocular antibiotics induce bacterial resistance at extraocular sites. Br J Ophthalmol 2005; 89: 1097-1099.

23 Bharathi MJ, Ramakrishnan R, Vasu S, Meenakshi R, Palaniappan R. Epidemiological characteristics and laboratory diagnosis of fungal keratitis. A three-year study. Indian J Ophthalmol 2003; 51: 315-321.

24 Bharathi MJ, Ramakrishnan R, Vasu S, Meenakshi R, Palaniappan R. In-vitro efficacy of antibacterials against bacterial isolates from corneal ulcers. Indian J Ophthalmol 2002; 50: 109-114. 